\title{
Aktivitas Mahasiswa dalam Pembelajaran Daring Berbasis Konferensi Video: Refleksi Pembelajaran Menggunakan Zoom dan Google Meet
}

\author{
Firman $^{1}$, Arlinda Puspita Sari², Firdaus ${ }^{3}$ \\ 1,2,3 Pendidikan Biologi Universitas Sulawesi Barat \\ firman@unsulbar.ac.id \\ (Received: 22-02-2021; Reviewed: 03-03-2021; Accepted: 26-03-2021)
}

\begin{abstract}
Abstrak
Penelitian ini bertujuan untuk mengkaji aktivitas mahasiswa dalam mengikuti perkuliahan daring berbasis konferensi video. Penelitian ini menggunakan pendekatan mix method yang menggabungkan metode kualitatif dan kuantitatif. Pengumpulan data dilakukan dengan wawancara dan menyebar angket. Hasil penelitian menunjukkan bahwa dalam perkuliahan daring yang dilaksanakan menggunakan applikasi konferensi video seperti Zoom dan Google Meet, mahasiswa cenderung melakukan aktivitas lain yang tidak berhubungan dengan perkuliahan. Aktivitas-aktivitas tersebut meliputi: (1) makan dan minum; (2) melamun; (3) menggunakan media sosial; (4) mengerjakan tugas mata kuliah lain; (5) memperhatikan tampilan layar teman kelas. Hasil penelitian ini dapat dijadikan sebagai bahan pertimbangan bagi pendidik dalam merancang perkuliahan daring sehingga potensi multitasking mahasiswa dalam pembelajaran dapat ditekan.
\end{abstract}

Kata Kunci: Pembelajaran daring, konferensi video, multitasking

\begin{abstract}
This research aims to investigate the students' activity during video conferencing based online lectures. This study uses a mix method approach that combines qualitative and quantitative methods. Data collection was carried out by interviewing and distributing 5 scale questionnaires. The results showed that in online lectures conducted using video conferencing applications such as Zoom and Google Meet, students tended to do other activities that were not related to lectures. These activities include: (1) eating and drinking; (2) mind wandering; (3) using social media; (4) doing other subject assignments; (5) pay attention to classmates' screen display. The results of this study can be used as a consideration for educators in designing online lectures to reduce the possibility of students multitasking in learning.
\end{abstract}

Keyword: Online learning, videoconferencing, multitasking

\section{PENDAHULUAN}

Covid-19 saat ini menjadi tantangan yang besar bagi sistem pendidikan di berbagai negara. Sebagai usaha untuk mencegah penyebaran Covid-19, pemerintah di seluruh dunia membuat kebijakan meniadakan pembelajaran secara tatap muka di sekolah maupun kampus. Pembelajaran yang sebelumnya diadakan di dalam kelas kini dialihkan ke rumah masing-masing. Hal ini kemudian menuntut berbagai institusi pendidikan beralih pada pendidikan virtual dan pembelajaran secara online (Daniel, 2020). Banyak pendidik yang sebelumnya tidak pernah mengajar menggunakan platform virtual dipaksa untuk beradaptasi dan memanfaatkan teknologi dalam pembelajaran dengan beralih pada media-media pembelajaran online (Smeraglio et al., 2020).

Pemanfaatan teknologi dalam pendidikan melalui pelaksanaan pembelajaran secara online menjadi alternatif yang banyak diambil oleh pendidik dan institusi pendidikan selama masa belajar 
dari rumah. Pembelajaran online dianggap mampu memfasilitasi interaksi, koneksi dan komunikasi antara pendidik dan peserta didik yang terpisah secara fisik. Pendidik dapat menjangkau dan berinteraksi dengan peserta didik dari mana saja dan kapan saja. Pelaksanaan pembelajaran secara online dapat menggantikan pembelajaran tatap muka dalam kelas, sekaligus meningkatkan kemampuan digital yang sejalan dengan perkembangan tren pendidikan saat ini (Onyema et al., 2020)

Pembelajaran online atau yang dengan istilah lain disebut sebagai pembelajaran daring, secara umum dapat dilaksanakan dengan dua cara yakni secara asinkron dan secara sinkron. Pembelajaran asinkron memungkinkan pendidik untuk memberikan bahan ajar yang dapat diakses oleh peserta didik pada waktu dan tempat yang berbeda. Sementara itu, pada pembelajaran secara sinkron, interaksi yang terjadi bersifat real time sehingga memungkinkan terjadinya komunikasi dua arah antara pendidik dan peserta didik pada waktu yang sama.

Baik pembelajaran asinkron maupun pembelajaran sinkron memiliki kelebihan dan kekurangan masing-masing. Akan tetapi, beberapa penelitian melaporkan peningkatan tren penggunaan pembelajaran online secara sinkron. Banyak institusi pendidikan yang melaksanakan pembelajaran daring secara sinkron dengan memanfaatkan teknologi konferensi video. Konferensi video merupakan pertemuan dimana pesertanya yang berada di lokasi berbeda dapat berkomunikasi satu sama lain secara audio dan visual (Sidpra et al., 2020). Beberapa platform konferensi video yang banyak digunakan untuk pembelajaran meliputi Zoom (Singhal, 2020), Google Meet (Al-Maroof et al., 2020) dan Cisco Webex (Brady \& Pradhan, 2020).

Penggunaan aplikasi-aplikasi konferensi video memungkinkan terjadinya pembelajaran secara sinkron meskipun pendidik dan peserta didik berada di lokasi yang berbeda. Pendidik dapat menyajikan bahan ajar dan memberikan penjelasan yang dapat langsung diakses dan disimak oleh peserta didik pada waktu yang sama. Meski demikian, pembelajaran dengan bentuk seperti ini memiliki beberapa keterbatasan yang menyebabkan pendidik tidak dapat dengan cermat mengamati aktivitas peserta didik selama pembelajaran berlangsung. Pendidik tidak dapat memastikan apakah peserta didik benar-benar mengikuti dan memperhatikan pembelajaran, ataukah mereka melakukan kegiatan-kegiatan lain yang tidak ada kaitannya dengan proses belajar.

\section{Metode}

Penelitian ini bertujuan untuk mengkaji aktivitas-aktivitas mahasiswa ketika mengikuti pembelajaran berbasis konferensi video. Dalam konteks penelitian ini, pembelajaran berbasis konferensi video merupakan pembelajaran yang dilaksanakan secara daring menggunakan aplikasi konferensi video seperti Zoom dan Google Meet. Penelitian ini menggunakan pendekatan mix method yang merupakan gabungan pendekatan kualitatif dan kuantitatif.

Data kualitatif dikumpulkan melalui wawancara menggunakan pedoman wawancara yang memuat pertanyaan-pertanyaan mengenai aktivitas mahasiswa ketika mengikuti pembelajaran berbasis konferensi video. Informan adalah mahasiswa Program Studi (Prodi) Pendidikan Biologi Fakultas Keguruan dan Ilmu Pendidikan (FKIP) Universitas Sulawesi Barat sejumlah 6 Orang, 4 responden berjenis kelamin perempuan dan 2 responden berjenis kelamin laki-laki. Wawancara dilakukan melalui telepon. Data hasil wawancara diolah menggunakan model analisis (Miles \& Huberman, 1994) yang meliputi reduksi data, display data, serta penarikan dan verifikasi kesimpulan. 
Temuan-temuan dari hasil wawancara dikembangkan menjadi angket mengenai aktivitas mahasiswa dalam pembelajaran daring berbasis konferensi video sebagai instrumen pengumpulan data secara kuantitatif. Angket terdiri atas 10 pernyataan dengan 5 pilihan tanggapan, yaitu (1) tidak pernah; (2) jarang; (3) kadang-kadang; (4) sering; (5) selalu. Angket disebar pada 108 mahasiswa Prodi Pendidikan Biologi FKIP Unsulbar dengan rincian 35 mahasiswa semester 1; 38 mahasiswa semester 5; dan 35 mahasiswa semester 7. Tanggapan yang diperoleh melalui angket selanjutnya dianalisis secara deskriptif.

\section{Hasil}

Hasil penelitian menunjukkan bahwa semua mahasiswa pernah mengikuti pembelajaran daring berbasis konferensi video. Beberapa pernyatan mahasiswa terkait hal ini adalah sebagai berikut: "Selama pandemi saya belajar dari rumah. Dosen kadang-kadang mengajar menggunakan Zoom ...” (Informan 1). "... saya lebih senang mengikuti kuliah online lewat Zoom karena dapat secara langsung mendengarkan penjelasan dosen” (Informan 2).

Secara umum dapat diketahui bahwa selama masa belajar dari rumah akibat pandemi Covid-19, mahasiswa mengikuti perkuliahan secara daring. Banyak mahasiswa yang lebih menyukai jika pembelajaran dilakukan menggunakan Zoom atau Google Meet. Walaupun demikian, terdapat kecenderungan mahasiswa untuk melakukan aktivitas-aktivitas lain ketika mengikuti perkuliahan berbasis konferensi video. Berikut adalah beberapa pernyataan mahasiswa terkait hal tersebut:

Ketika mengikuti kuliah lewat Zoom, saya selalu berusaha memperhatikan penjelasan materi yang diberikan dosen. Saya mencatat penjelasan-penjelasan penting yang diberikan oleh dosen. Akan tetapi di tengah perkuliahan saya sering merasa bosan dimana saya sulit untuk berkonsentrasi memperhatikan perkuliahan (Informan 3)

Kadang-kadang saya tidak bisa memperhatikan materi di Zoom dengan baik karena saya lebih banyak chatting-an dengan teman di WA. Kami sering membahas hal-hal yang tidak berkaitan dengan materi yang diajarkan dosen, ... Kadang-kadang saya lebih suka memperhatikan video atau foto teman saya di Zoom daripada memperhatikan ppt materi yang dijelaskan dosen (Informan 4)

Saya sering mematikan kamera Zoom agar tidak dilihat oleh dosen. Kalau kamera saya mati saya bisa makan dan minum. Saya juga biasa bermain Instagram atau Facebook. Kadang-kadang saya meninggalkan laptop di kamar jika saya ingin ke WC sehingga saya tidak mendengar semua penjelasan dosen. (Informan 5)

Semua mata kuliah melakukan belajar online sehingga banyak sekali tugas yang harus saya kerjakan. Saya sering mengikuti kuliah di Zoom sambil mengerjakan tugas dari dosen lain supaya saya tidak terlambat dalam mengumpulkan tugas itu. akhirnya saya tidak fokus memperhatikan penjelasan dosen dan tidak terlalu mengerti materi perkuliahan yang dijelaskan (Informan 6).

Hasil pemadatan fakta yang diperoleh dari transkrip wawancara menunjukkan bahwa ada beberapa aktivitas tidak terkait pembelajaran yang sering dilakukan oleh mahasiswa ketika mengikuti perkuliahan daring berbasis konferensi video. Aktivitas-aktivitas tersebut mencakup: 1) makan dan minun; (2) melamun; (3) menggunakan media sosial; (4) mengerjakan tugas mata kuliah lain; (5) memperhatikan tampilan layar teman kelas. 
Informasi di atas selanjutnya dikembangkan menjadi angket aktivitas mahasiswa dalam pembelajaran berbasis konferensi video. Secara umum, hasil analisis angket tersebut dapat dilihat pada Tabel 1 berikut:

Tabel 1. Aktivitas mahasiswa dalam pembelajaran daring berbasis konferensi video

\begin{tabular}{lc}
\hline \multicolumn{1}{c}{ Pernyataan } & $\begin{array}{c}\text { Tanggapan } \\
\text { Mahasiswa (\%) }\end{array}$ \\
\hline Pernah mengikuti perkuliahan daring menggunakan applikasi konferensi video & 100 \\
\hline $\begin{array}{l}\text { Me-non-aktifkan kamera selama perkuliahan berbasis konferensi video agar } \\
\text { aktivitas saya tidak terlihat oleh dosen }\end{array}$ & 72,41 \\
\hline Makan/minum/ngemil selama perkuliahan daring berbasis konferensi video & 82,78 \\
\hline Melamun ketika mengikuti perkuliahan daring berbasis konferensi video & 72,41 \\
\hline Bermain sosial media selama pembelajaran daring berbasis konferensi video & 81,67 \\
\hline $\begin{array}{l}\text { Mengerjakan tugas mata kuliah lain selama perkuliahan berbasis konferensi } \\
\text { video }\end{array}$ & 85,74 \\
\hline $\begin{array}{l}\text { Lebih tertarik memperhatikan tampilan layar teman saya dibanding tampilan } \\
\text { materi yang dijelaskan oleh dosen }\end{array}$ & 79,07 \\
\hline $\begin{array}{l}\text { Lebih banyak bertanya atau mengemukakan pendapat ketika mengikuti } \\
\text { perkuliahan daring berbasis konferensi video dibandingkan pada perkuliahan } \\
\text { tatap muka dalam kelas }\end{array}$ & 68,89 \\
\hline $\begin{array}{l}\text { Mencatat poin-poin penting dari penjelasan dosen pada saat mengikuti } \\
\text { perkuliahan daring berbasis konferensi video }\end{array}$ & 66,85 \\
\hline $\begin{array}{l}\text { Lebih banyak melakukan aktivitas lain yang tidak berkaitan dengan perkuliahan } \\
\text { dibandingkan memperhatikan penjelasan materi. }\end{array}$ & 84,26 \\
\hline
\end{tabular}

\section{Pembahasan}

Hasil penelitian mengungkapkan bahwa mahasiswa menunjukkan kecenderungan lebih menyukai pembelajaran secara sinkron melalui konferensi video dibandingkan pembelajaran asinkron yang dilaksanakan menggunakan applikasi-applikasi pembelajaran online. Pembelajaran melalui Zoom atau Google Meet dianggap lebih baik karena memungkinkan untuk berkomunikasi secara langsung dengan dosen ataupun rekan mahasiswa yang lain.

Survey yang dilakukan oleh Sidpra et al. (2020) terhadap 50 mahasiswa dan dosen mengungkapkan bahwa 92\% responden pernah melaksanakan atau mengikuti pembelajaran sinkron melalui konferensi video, dan $88 \%$ diantaranya menyatakan puas dengan pembelajaran tersebut. Pembelajaran secara sinkron menggunakan layanan konferensi video memungkinkan pendidik dan peserta didik berinteraksi secara real time sekaligus mengurangi potensi tertundanya feedback seperti yang biasa terjadi pada pembelajaran yang dilaksanakan secara asinkron, mendukung interaksi kelompok, serta menyediakan ruang untuk berbagi opini dan berdiskusi dalam kelompok kecil (Gillies, 2008; Correia, Liu, \& Xu, 2020).

Walaupun demikian, terdapat indikasi bahwa mahasiswa kesulitan mempertahankan fokus dalam mengikuti perkuliahan online menggunakan aplikasi konferensi video. Seiring berjalannya perkuliahan, mahasiswa secara berangsur mengalami kesulitan untuk konsentrasi dalam mengikuti 
proses pembelajaran dan memperhatikan materi melalui layar laptop ataupun telepon pintar mereka. Hal ini dipicu oleh kondisi fisik serta hal-hal eksternal. Noermalia \& Irwansyah (2020) menyebutkan beberapa distraksi peserta didik dalam pembelajaran berbasis konferensi video adalah distraksi dari orang-orang di rumah, distraksi suasana kamar yang membuat mengantuk, notifikasi dari platform lain, serta distraksi dari teman yang tidak mematikan mikrofon saat proses pembelajaran.

Pada konteks pembelajaran daring berbasis konferensi video yang dilakukan pendidik dan diikuti peserta didik dari rumah masing-masing, dosen dan mahasiswa berada pada lokasi yang berbeda. Hal ini menciptakan batasan ruang yang membuat dosen kesulitan untuk mengamati secara langsung apa yang dilakukan mahasiswa selama pembelajaran. Ketiadaan dosen secara fisik membuat mahasiswa merasa tidak diawasi sehingga tidak ada tekanan bagi mereka untuk tetap memperhatikan perkuliahan yang sedang berlangsung. Selain itu, akibat keterbatasan jaringan mahasiswa diperbolehkan untuk tidak mengaktifkan kamera sehingga semakin sulit bagi dosen untuk memantau aktivitas mahasiswa selama pembelajaran.

Banyak buku dan artikel tentang pembelajaran yang menyatakan bahwa peserta didik hanya dapat memperhatikan materi pembelajaran di dalam kelas pada rentang waktu tertentu. Rata-rata rentang perhatian peserta didik pada pelajaran di dalam kelas adalah antara 10-15 menit. Pada lingkungan pembelajaran online, dosen dan mahasiswa berada di tempat yang terpisah. Adanya perbedaan lokasi dosen dan mahasiswa pada pembelajaran daring membuat dosen tidak bisa memantau secara langsung aktivitas mahasiswa sehingga tidak ada jaminan bahwa mereka benarbenar memperhatikan pembelajaran (Wilson \& Korn, 2007; Bunce, Flens, \& Neiles, 2010; Szpunar et al., 2013)

Kecenderungan mahasiswa melakukan banyak aktivitas lain merupakan fenomena yang umum diamati dalam pembelajaran daring. Banyak bukti yang menunjukkan bahwa mahasiswa menghabiskan banyak waktu untuk melakukan hal-hal yang bersifat non akademik ketika menggunakan laptop atau perangkat lain yang terhubung dengan internet. Kecenderungan ini menurut banyak penelitian dinilai berpengaruh buruk pada hasil belajar, akan tetapi perilaku ini sangat sulit untuk dikendalikan terutama pada kelas-kelas online (Lepp et al. 2019; Alghamdi et al., 2020; Schmidt, 2020)

Salah satu aktivitas yang cukup banyak dilakukan mahasiswa selama pembelajaran daring berbasis konferensi video adalah melamun (mind wandering). Ketika mahasiswa melamun, secara fisik mereka terlihat mengikuti pembelajaran di depan laptop atau telepon pintar masing-masing, akan tetapi pikiran mereka berada di tempat lain dan tidak terfokus pada materi yang sedang dibahas dalam perkuliahan.

Melamun (mind wandering) merupakan peralihan pikiran dari aktivitas yang sedang berlangsung ke pikiran-pikiran yang tidak terkait dengan aktivitas tersebut. Pada konteks pendidikan, melamun umum ditemui dalam proses belajar, baik dalam pembelajaran tatap muka maupun dalam pembelajaran online. Seseorang dapat melamun selama 30\%-50\% dari waktu mereka dalam sehari. Fenomena ini berpotensi mempengaruhi pencapaian hasil belajar peserta didik karena melamun dapat menyebabkan kesalahan terutama dalam aktivitas-aktivitas yang membutuhkan konsentrasi dan menuntut secara kognitif (Szpunar et al., 2013; Hollis \& Was, 2016). 
Selain itu, aktivitas lain yang juga cukup banyak dilakukan oleh mahasiswa ketika mengikuti perkuliahan daring adalah menggunakan media sosial. Banyak mahasiswa yang mengikuti pembelajaran sambil berkirim pesan melalui WhatsApp bersama teman-temannya. Mereka juga seringkali memperbarui status pada Facebook atau mengunggah kiriman di Instagram. Mahasiswa juga kadang-kadang lebih tertarik mengamati tampilan video temannya dibandingkan slide presentasi yang disajikan oleh dosen.

Sangat sulit untuk memastikan bahwa mahasiswa memperhatikan materi pembelajaran ketika mengikuti perkuliahan secara online . Koneksi dengan jaringan internet memungkinkan mahasiswa untuk mengakses barbagai konten pada waktu yang bersamaan dan berpotensi mengalihkan perhatian mereka dari pembelajaran, termasuk didalamnya adalah media sosial. Banyak penelitian yang menilai bahwa sosial media dapat mengganggu proses pembelajaran. (Andersson, Hatakka, Grönlund, \& Wiklund, 2014; Purvis, Rodger, \& Beckingham, 2016; Hollis \& Was, 2016)

Melakukan dua atau lebih hal secara simultan (Multitasking) dalam pembelajaran menjadi hal yang umum dilakukan oleh mahasiswa, terutama dalam mengikuti perkuliahan yang dilaksanakan secara online. Mengikuti pembelajaran sambil melakukan aktivitas lain, misalnya mengerjakan tugas mata kuliah lain, membuat perhatian mahasiswa terbagi sehingga pengalaman belajar yang mereka dapatkan menjadi tidak maksimal. Hal ini dapat berpengaruh pada hasil belajar dan performa mahasiswa secara keseluruhan dalam perkuliahan.

Schmidt (2020) mengungkapkan bahwa secara umum otak manusia tidak bisa memproses dua atau lebih aktivitas kompleks secara simultan. Multitasking hanya dapat terjadi jika aktivitasaktivitas yang dilakukan cukup sederhana dan tidak melibatkan sumber mental yang sama, misalnya kita dapat melipat baju sambil mendengarkan radio secara bersamaan. Berbagai penelitian menunjukkan bahwa multitasking memiliki pengaruh pada pembelajaran. Tingkat penggunaan laptop pada pembelajaran dalam kelas, jumlah waktu yang dihabiskan mahasiswa dalam menggunakan aplikasi pesan instan, serta durasi mahasiswa dalam menggunakan facebook dilaporkan memiliki korelasi negatif dengan prestasi dan pencapaian hasil belajar mahasiswa (Lee et al., 2012).

Terdapat indikasi bahwa salah satu alasan mahasiswa melakukan multitasking dalam pembelajaran adalah untuk mengatasi rasa bosan dan lelah yang mereka rasakan selama perkuliahan. Selama masa darurat Covid-19, mahasiswa mengikuti perkuliahan dari rumah masingmasing. Dalam sehari mahasiswa dapat mengikuti lebih dari satu perkuliahan daring menggunakan aplikasi konferensi video. Selama perkuliahan tersebut, mahasiswa kebanyakan hanya memperhatikan layar laptop atau layar telepon pintar untuk menyimak materi dan penjelasan dosen.

Sklar (2020) menjelaskan bahwa banyak orang yang merasa kelelahan ketika melakukan konferensi video. Fenomena ini disebut sebagai Zoom fatigue walaupun keadaan yang sama juga terjadi pada pengguna Google Hangout, Skype, FaceTime, ataupun aplikasi panggilan video lainnya. Panggilan video membutuhkan lebih banyak konsentrasi dibandingkan komunikasi secara tatap muka. Dalam melakukan panggilan video kita harus bekerja lebih keras untuk mengolah informasi non verbal seperti ekspresi, nada dan tekanan suara, bahasa tubuh; memperhatikan hal-hal tersebut membutuhkan lebih banyak energi (Jiang, 2020).

Terdapat banyak faktor yang diduga memicu multitasking mahasiswa dalam pembelajaran daring, terutama yang dilaksanakan menggunakan aplikasi konferensi video. Beberapa diantaranya 
termasuk kesiapan mahasiswa dalam mengikuti pembelajaran, metode dan model pembelajaran yang digunakan oleh dosen, serta kondisi-kondisi internal dan eksternal lain yang dapat mempengaruhi proses belajar mahasiswa. Untuk itu perlu diadakan penelitian lebih lanjut dengan metode yang sistematis untuk mengkaji faktor-faktor penyebab disengagement yang pada gilirannya dapat mendorong mahasiswa untuk melakukan aktivitas lain yang tidak terkait dengan pembelajaran.

\section{Kesimpulan}

Temuan yang diperoleh dalam penelitian ini mengungkapkan bahwa selama pembelajaran daring berbasis konferensi video, mahasiswa memiliki kecenderungan melakukan aktivitas-aktivitas yang tidak ada kaitannya dengan pembelajaran. Aktivitas-aktivitas tersebut meliputi: (1) makan dan minun; (2) melamun; (3) menggunakan media sosial; (4) mengerjakan tugas mata kuliah lain; (5) memperhatikan tampilan layar teman kelas. Informasi ini dapat dijadikan sebagai bahan pertimbangan bagi pendidik dalam merancang pembelajaran daring berbasis konferensi video sehingga potensi-potensi munculnya aktivitas yang dapat mengalihkan perhatian mahasiswa dalam perkuliahan dapat diminimalisir.

\section{Referensi}

Al-Maroof, R. S., Salloum, S. A., Hassanien, A. E., \& Shaalan, K. (2020). Fear from COVID-19 and technology adoption: the impact of Google Meet during Coronavirus pandemic. Interactive Learning Environments. https://doi.org/10.1080/10494820.2020.1830121

Andersson, A., Hatakka, M., Grönlund, Å., \& Wiklund, M. (2014). Reclaiming the students coping with social media in 1:1 schools. Learning, Media and Technology. https://doi.org/10.1080/17439884.2012.756518

Brady, A. K., \& Pradhan, D. (2020). Learning without Borders: Asynchronous and Distance Learning in the Age of COVID-19 and Beyond. ATS Scholar, 1(3), 233-242. https://doi.org/10.34197/ats-scholar.2020-0046ps

Bunce, D. M., Flens, E. A., \& Neiles, K. Y. (2010). How long can students pay attention in class? A study of student attention decline using clickers. Journal of Chemical Education. https://doi.org/10.1021/ed100409p

Correia, A. P., Liu, C., \& Xu, F. (2020). Evaluating videoconferencing systems for the quality of the educational experience. Distance Education. https://doi.org/10.1080/01587919.2020.1821607

Daniel, S. J. (2020). Education and the COVID-19 pandemic. Prospects. https://doi.org/10.1007/s11125-020-09464-3

Gillies, D. (2008). Student perspectives on videoconferencing in teacher education at a distance. Distance Education. https://doi.org/10.1080/01587910802004878

Hollis, R. B., \& Was, C. A. (2016). Mind wandering, control failures, and social media distractions in online learning. Learning and Instruction. https://doi.org/10.1016/j.learninstruc.2016.01.007 Jiang, manyo. (2020). The reason Zoom calls drain your energy - BBC Worklife. BBC. 
Lee, J., Lin, L., \& Robertson, T. (2012). The impact of media multitasking on learning. Learning, Media and Technology. https://doi.org/10.1080/17439884.2010.537664

Lepp, A., Barkley, J. E., Karpinski, A. C., \& Singh, S. (2019). College Students' Multitasking Behavior in Online Versus Face-to-Face Courses. SAGE Open. https://doi.org/10.1177/2158244018824505

Miles, M. B., \& Huberman, M. (1994). Qualitative Data Analysis Second Edition. In SAGE Publications.

Noermalia, T., \& Irwansyah, I. (2020). Penerimaan Teknologi Konferensi Video dan Motivasi Belajar. Jurnal Komunikasi, 12(2), 246. https://doi.org/10.24912/jk.v12i2.8653

Onyema, E. M., Eucheria, N. C., Obafemi, F. A., Sen, S., Atonye, F. G., Sharma, A., \& Alsayed, A. O. (2020). Impact of Coronavirus Pandemic on Education. Journal of Education and Practice, 11(13), 108-121. https://doi.org/10.7176/jep/11-13-12

Purvis, A., Rodger, H., \& Beckingham, S. (2016). Engagement or distraction: the use of social media for learning in higher education. Student Engagement and Experience Journal. https://doi.org/10.7190/seej.v5.i1.104

Schmidt, S. J. (2020). Distracted learning: Big problem and golden opportunity. Journal of Food Science Education, 19(4), 278-291. https://doi.org/10.1111/1541-4329.12206

Sidpra, J., Gaier, C., Reddy, N., Kumar, N., Mirsky, D., \& Mankad, K. (2020). Sustaining education in the age of COVID-19: A survey of synchronous web-based platforms. In Quantitative Imaging in Medicine and Surgery (Vol. 10, Issue 7, pp. 1422-1427). AME Publishing Company. https://doi.org/10.21037/QIMS-20-714

Singhal, M. K. (2020). Facilitating virtual medicinal chemistry active learning assignments using advanced zoom features during covid-19 campus closure. Journal of Chemical Education, 97(9), 2711-2714. https://doi.org/10.1021/acs.jchemed.0c00675

Sklar, J. (2020). 'Zoom fatigue' is taxing the brain. Here's why that happens. | National Geographic. National Geographic.

Smeraglio, A., DiVeronica, M., Terndrup, C., McGhee, B., \& Hunsaker, S. (2020). Videoconferencing: A Steep Learning Curve for Medical Educators. Journal of Graduate Medical Education, 12(5), 553-556. https://doi.org/10.4300/JGME-D-20-00514.1

Szpunar, K. K., Moulton, S. T., \& Schacter, D. L. (2013). Mind wandering and education: From the classroom to online learning. In Frontiers in Psychology. https://doi.org/10.3389/fpsyg.2013.00495

Wilson, K., \& Korn, J. H. (2007). Attention during Lectures: Beyond Ten Minutes. Teaching of Psychology. https://doi.org/10.1080/00986280701291291 